\title{
On the Refugee Crisis Discourse: A Critical Analysis Sitting in the Junction of International Criminal Law and International Refugee Law
}

\author{
Ekin Deniz Uzun* ${ }^{*}$
}

\begin{abstract}
This Article critically explores the close relationship between the discourse of the refugee crisis phenomenon and inattentive state policies against refugees. Various reproduced political approaches of states appearing as a result of 'how to deal with refugee crisis' concern across the world are exemplified to this end. In this light, it is asked whether certain forms of abuse occur due to the states' way of regulating refugees' asylum, and whether the process can be elevated to the level of crimes against humanity under the Rome Statute. The goal is to understand this issue by involving international criminal law and in connecting it to the International Criminal Court to determine whether states can be precluded from creating an environment that possibly leaves refugees vulnerable to both physical and sexual abuse, e.g., in detention centers or refugee camps. In relation to that, it is also expounded in what ways the refugee crisis as a produced concept by the conservative propaganda configures the attitude of both individuals and policy makers towards refugees. The adverse image, that is portrayed for refugees, effects negatively not only on the public view but also normalizes states' othering attitude when it comes to responding and regulating the movements of outsiders. In this direction, the 1951 Refugee Convention, the Rome Statue, and some other relevant international legal instruments are taken into account to examine the perpetrated violence employed by states through their policies against refugees. Drawing upon this dispute, evil wrongdoers, victimhood and refugee person as homo sacer are conceptualized alongside the crisis narrative throughout this Article, both from a philosophical and socio-legal standpoint.
\end{abstract}

\section{Keywords}

Refugee, International criminal law, International refugee law, Crisis discourse, Refugee protection, Crimes against humanity

Mülteci Krizi Söylemi Üzerine: Uluslararası Ceza Hukuku ve Uluslararası Mülteci Hukuku’nun Kesişim Noktasına Oturan Kritik Bir Inceleme

\section{Öz}

Bu makale, mülteci krizi olgusu söylemi ile mültecilere karşı istismarcı devlet politikaları arasındaki yakın ilişkiyi inceler. 'Mülteci krizi ile nasıl başa çıkılacağı' endişesinin bir sonucu olarak ortaya çıkan devlet politikaları bu amacı açıklamak amacıyla örnek oluşturmaları itibariyle makale kapsamında incelenir. Bu bağlamda, bazı devletlerin mültecilerin iltica başvuru sürecine ilişkin getirdikleri işleyiş dolayısıyla ortaya çıkan istismarcı muamelelerinin, Roma Statüsü uyarınca insanlığa karşı işlenen suçlar düzeyinde değerlendirilip değerlendirilemeyeceği sorgulanmaktadır. Amaç, uluslararası ceza hukukunun sürece dahil edilmesiyle, Uluslararası Ceza Mahkemesi'nin devletlerin mültecileri hem fiziksel hem de cinsel istismara karşı savunmasız bırakabilecek bir ortam yaratmasının engellenip engellenemeyeceğini anlamaktır. Muhafazakar propaganda tarafindan üretilen bir kavram olarak mülteci krizinin hem bireylerin hem de politikacıların mültecilere karşı tutumunu nasıl yapılandırdığı da bu çerçevede açıklanır. Mülteciler için tasvir edilen olumsuz imaj, sadece kamuoyunun görüşünü negatif yönde etkilemekle kalmamakta, aynı zamanda 'yabancıların' ülkeye giriş çıkışlarını

* Corresponding author: Ekin Deniz Uzun (Lec. Dr.), Ankara Yıldırım Beyazıt University, Faculty of Law, Department of International Law, Ankara, Turkey. E-mail: eduzun@ybu.edu.tr ORCID: 0000-0002-9757-0223

Citation: Uzun E. D., “On the Refugee Crisis Discourse: A Critical Analysis Sitting in the Junction of International Criminal Law and International Refugee Law” (2020) 78(4) İstanbul Hukuk Mecmuası 2025. https://doi.org/10.26650/mecmua.2020.78.4.0010 
düzenlemek konusunda devletlerin istismarcı tutumlarını da normalleştirmektedir. Bu doğrultuda, 1951 Mülteci Sözleşmesi, Roma Statüsü ve diğer bazı ilgili uluslararası yasal belgeler, mültecilere yönelik politikalar eliyle devletlerin onlara karşı uyguladığı şiddeti incelemede dikkate alınmıştır. Tüm bu tartşmalar etrafinda, haksızlık eden kimseler/kurumlar, mağduriyet ve homo sacer olgusu bağlamında mülteci kavramları, kriz söylemi etrafinda, hem felsefi hem de sosyo-legal açılarından kavramsallaştrılarak incelenmiştir.

\section{Anahtar Kelimeler}

Mülteci, Uluslararası ceza hukuku, Uluslararası mülteci hukuku, Kriz söylemi, Mültecilerin korunması, İnsanlığa karşı suçlar 


\section{Extended Summary}

This study looks at refugee crisis discourse through the lens of international criminal law (ICL) and international refugee law (IRL) by asking the following question and raising following concerns respectively: in what ways the crisis, refugee and victimhood phenomena describe mass human movement in the modern world. As we get more attached to see violence in the news ranging from racism to armed conflict, it is sought to answer whether we also reflect this rage on refugees by marginalizing them in the end. In order to get some sense on this question, the role of conservative discourse and its extended state policies are analyzed to understand how they seed a negative image in the collective memory of societies about refugees. It is set to identify the problem that this created collective memory discerns refugees as evil wrong doers who breach every right possible that are attributed to states. This also justifies states' way of crushing refugees bodily and spiritually to obstruct future refugees from arriving on their soils. The presented mindset herein also absolves states from abusive acts of their agents. In that we are conditioned to conclude that mistreatment of refugees is not grave enough to be considered within the context of crimes against humanity for instance; even though requirements for this international crime are present. Indeed, some scholars and public figures have taken action to get the International Criminal Court (ICC) involve holding governments and state agents responsible from their atrocious methods employed against refugees. However, in consideration of the major incidents and recent developments including failed correspondences with the ICC Office of The Prosecutor (OTP) in this regard, this Article asks whether international criminal law can really resolve the consequences of refugee crisis discourse at the end of the day.

In pursuance of this question respectively the rhetoric of refugee crisis and its consequences are discussed both from a philosophical and legal standpoint. The evil nature of overwhelming incidents -constituting the misery of refugees in the hands of state of asylum- keep surfacing through news media and academic discussions, which have triggered an urge in international community to find a solution to these sequential matters. Some leading books have been written in respect to the consequential effects of refugee crisis discourse, to name a few: Solidarity and 'Refugee Crisis' in Europe by Óscar García Agustín and Martin Bak Jørgensen; Asylum Seekers, Sovereignty, and the Senses of the International edited by Jenny Edkins and Nick Vaughan-Williams; Asylum Seekers and Refugees in the Contemporary World by David J.Whittaker; Refuge Transforming A Broken Refugee System by Alexander Betts and Paul Collier. The crimes against humanity aspect of cruel treatment against refugees have been analysed by Ioannis Kalpouzos, Itamar Mann, Kevin Jon Heller and some other researchers cited within the context of this Article too. Merging all of these analyses and real-world examples, this study agrees that even if the elements 
of crimes against humanity come together with respect to treatment against refugees, still states will be reluctant to take refugee protection measures more seriously, if there are no consequences for not reducing any form of violence. Indeed recent correspondences with the OTP have shown that it is the ICC that is hesitant to pursue further investigation on related matters in the first place; for instance what has been going on in the Australian offshore detention centers. This Article in this respect looks at the incidents in which people escape from persecution due to race, religion, armed conflict, international crimes etc, and are victimized further due to receiving states' atrocious conducts. This aspect brings together two disciplines of international law -namely ICL and IRL- to find solution whether inattentive states' policies, get shaped/influenced by refugee crisis discourse, can be eliminated. As is concluded in the final part of this Article, recent examples and research prove us that as long as influential institutions, in particular ICC, remain silent on the face of growing discriminative politics, these countries who other 'outsiders' without having extrinsic pressure on them to refrain from any abusive treatments, will continue to get away with their legislations and policies in their limits and powers that will help and encourage these states to keep refugees out. 


\section{Introduction}

This Article proceeds in three main parts by directing its focus on the major central challenges detailed in the following paragraphs.

Part I looks over the anatomy of forced migration related phenomena, namely the refugee and asylum seeker. This analysis acknowledges that refugee and asylum seekers are meant to describe two different stages and status arising as a result of people fleeing due to "well-founded fear of being persecuted for reasons of race, religion, nationality, membership of a particular social group or political opinion". ${ }^{1}$ As is explained in this part, the term refugee is widely used by the media and international community as a catchall term involving asylum seekers. In the aim of explaining the refugee crisis discourse, this Article uses the term refugee to describe the various stages of the journey that includes the duration when people are forced to move and cross-national borders, until the end when claims of individuals who have been forced to migrate are processed and decided by the agencies of the state of asylum or the United Nations Commissioner for Refugees (UNHCR).

Part II examines the concept of refugee crisis from a legal and philosophical standpoint. It first criticizes the produced concept of a crisis that is used to describe incidences and related consequences of movements of refugees. Respectively, this part sets out the meaning of becoming a refugee in reference to the Universal Declaration of Human Rights (UDHR) Article 14. ${ }^{2}$ This very acceptance stands as a driving force for this study to find out what qualifies 'everyone' set out within the context of this Article.

Part III looks at major relevant incidences that describe people fleeing from persecution. The goal is to conclude whether treatments conducted by states to discourage movement of refugees may amount to international crimes, in particular crimes against humanity defined under the Rome Statute. ${ }^{3}$ Similar series of analysis have been already conducted by some scholars, e.g., regarding Australian policy on refugees on Manus Island, as is stated above. Departing from these analyses, the incidences that also include natural 'alert mode' of people to flee from battlefield is examined through the lens of International Criminal Law (ICL).

The final part brings together all of these ongoing analyses to answer the question of whether ICL can resolve the refugee crisis problem. Through outstanding academic works and correspondences with the International Criminal Court (ICC) and Office of

Convention Relating to the Status of Refugees (adopted 28 July 1951, entered into force 22 April 1954) 189 UNTS 137 (Thereafter 1951 Refugee Convention), Article 1(A)(2) defines the phenomenon of refugee.

Further see Protocol relating to the Status of Refugees (adopted 31 January 1967, entered into force 4 October 1967 ) 606 UNTS 267 (Thereafter 1967 Protocol).

See Universal Declaration of Human Rights (adopted 10 December 1948 UNGA Res 217 A(III) (UDHR) art 14.

Rome Statute of the International Criminal Court, July 17, 1998, 2187 U.N.T.S. 90. 
The Prosecutor (OTP), the problems have been identified and certain solutions have been developed/offered regarding protection of refugees from inattentive and abusive state policies. However, one way or another it seems neither the ICL nor the ICC have developed an 'automatic' response regarding this concern. What international law can do to remedy the quagmire emerging out of the refugee crisis rhetoric is concluded in this part.

The overall analysis of this Article aims to connect International Refugee Law (IRL) and ICL by examining the cases that include perpetrated violence conducted against refugees by state of asylum. It means that the 1951 Refugee Convention Article $1(\mathrm{~F})$ remains out of the scope of analysis conducted herein. Articles 1(A)(2) and 1(F) (a) of the 1951 Refugee Convention are termed as the inclusion and the exclusion clauses in turn. The inclusion clause sets out the criteria in which cases someone should be recognized as a refugee. The exclusion clause is designed to prevent persons who commit international crimes (e.g., regulated under the Rome Statute) to benefit from refugee status. For example, the use of torture under President Bashar al-Assad's rule is examined for the first time by the German Court. As jus cogens international crimes, crimes against humanity and war crimes are "presumed to carry the obligation to prosecute or extradite, and to allow States to rely on universality for prosecution, punishment, and extradition". ${ }^{4}$ Germany, by following this acceptance, tried two men who fled Syria due to ongoing civil war. They both applied for asylum in Germany. However, they got arrested. ${ }^{5}$ Allegedly they had committed war crimes in Syria which was considered within the realm of the exclusion clause of the Refugee Convention. This case can be examined in two folds: First it provides us with an example that persons who commit international crimes cannot seek a safe haven in other states, as it is not only prohibited legally but also practically it has been prevented by receiving states - in this example in Germany. This incidence further proves to us that receiving states have influential roles in eliminating the most outrageous crimes, if the state authorities do not turn a blind eye to the atrocities already committed on foreign lands. However, as is exemplified further, in the face of increasing mass movement of humans, receiving states have become perpetrators victimizing the ones who seek safe haven outside of their homelands.

Once and for all, this Article intends to eliminate the attitude of refugee crisis terminology through the following approach: emergency response to the needs of refugee persons. This convergence with its terminological intent serves to indicate different dimensions of the same problem: At first, it contains the urgent need of the movement of people fleeing to request asylum from another state. This journey

\footnotetext{
M Cherif Bassiouni, 'Universal Jurisdiction for International Crimes: Historical Perspectives and Contemporary Practice' (2001-2002) 42(1) Virginia Journal of International Law 81, 119.

See BBC News, 'Syria civil war: Germany holds unprecedented state torture trial' (BBC, 23 April 2020) <https://www.bbc. com/news/world-europe-52393402> Date of access 23 April 2020.
} 
includes pain of people, which includes mental as well as physical distress. Second, the way of seeing the 'problem' appreciates migration as structural inequality -political and economic- triggered by violence and danger. ${ }^{6}$ In the inspiration of Jean-Francois Durieux, emergency response understands that the negative incidences (as exemplified within the context of this Article) emerging out of the movement of people across borders can be categorized as urgent - needing an immediate response. ${ }^{7}$ Conceived in these terms arising through emergency response -both as a result of force and being in need of searching for a better/safer place to live due to persecutionthe danger of refugee crisis conceptualization is explained in more detail after the analysis on the intrinsic characteristics of the forced migration related phenomena given in the following paragraphs.

\section{Intrinsic Characteristics of Forced Migration Related Phenomena}

This Article in pursuance of its research question -can international criminal law resolve the consequences of refugee crisis discourse- deals in fact with issues link to forced migration. By and large, considering the complex nature of forced migration related problems, it is important to clarify certain phenomena as in asylum seeker and refugee.

Generally speaking, seeking a refuge somewhere other than one's homeland is categorized under the term migration. Migration as a term is the everyday parlance for any kind of human movement in the broadest sense possible: people move overseas, cross borders and seek sanctuary elsewhere due to economic, environmental reasons; or they merely escape from violence including racism, misogynism, armed conflict, etc. The United Nations High Commission for Refugees (UNHCR) defines the asylum seeker as "[a]n individual who is seeking international protection". ${ }^{8}$ It means that the claim of the asylum seeker has not yet been finalized by the country in which the claim had been submitted; this also makes every refugee initially an asylum-seeker. People who are not able to return to their home states for any number of reasons have found themselves in a ceaseless transition state. In order for them to have their basic rights met, the receiving state or the UNHCR has to go through a procedural process that would put asylum seekers in line to be recognized as refugees, giving them their de jure status: only then "satisfying the relevant criteria will indicate entitlement to the pertinent rights or benefits". ${ }^{9}$ This process is referred to as refugee status determination by the UNHCR.

Kalpouzos I, 'International Criminal Law and the Violence against Migrants' (2020) 21 German Law Journal 571, 577.

Jean-Francois Durieux, 'The Duty to Rescue Refugees' (2016) 28 Int'1 J Refugee L 637, 641.

UNHCR, 'Glossary'<https://www.unhcr.org/449267670.pdf441> Date of access 24 June 2020.

Guy Goodwin-Gill, The Refugee in International Law ( $2^{\text {nd }}$ d, Oxford: Clarendon Press 1996), 2. 
In the cases of armed conflicts and incidences that include systematic human rights violations, individuals mostly flee from this violence resulting in countries en masse. Evidently, it would be impractical for receiving states to examine each individual asylum application. For this reason, in these cases fleeing individuals are referred to as prima facie refugees.

It is acknowledged within the context of this research that legally asylum seeker and refugee are meant to describe different terms. However, within academia and media, e.g., the refugee crisis phenomenon is mostly used to include 'issues' linked with asylum seekers too. This study uses the term of refugee to include asylum seekers and prima facie refugees who are in a transition state and waiting to attain their refugee statutes. Related modern world incidences involving the refugee status determination process that keep refugees waiting in refugee camps, detention centers or some other accommodation facilities in this respect are narrated further down by using the refugee wording as an expletive phenomenon. In this regard, the following definition for refugee person can be taken as a reference for this Article's reconnoiter:

"A person is a refugee within the meaning of the 1951 Convention as soon as he fulfils the criteria contained in the definition... He does not become a refugee because of recognition, but is recognized because he is a refugee."10

The ultimate question in this context aims to understand in what ways states' disincentive policies towards refugees get shaped by racist conservative discourse: whether certain forms of abuse -as a result of the states' way of handling refugeescan be elevated to the level of crimes against humanity? Indeed, this question has been discussed by some scholars and brought its attention to the International Criminal Court (ICC). For instance, we now know that after the correspondence between the OTP and the Independent MP Andrew Wilkie from Australia, the OTP acknowledged Australia's policy of mandatory offshore detention for asylum seekers as constituting cruel, inhuman or degrading treatment. However, the OTP declined to open a preliminary examination to consider such conditions in relation to crimes against humanity. The reasons coming from the Prosecutor can be summarized as the Government's policies not being deliberate and the asylum seekers not being lawfully present in the area where they were being deported from. Building upon this epitomic case, this Article looks at the applicability of gravity requirement of crimes against humanity by linking this analysis with the deliberate nature of related acts (conducted in Australian offshore detention centers and some other refugee camps) in light of the modern world incidences. The goal is to show readers that mistreatment against refugees encouraged by the states' political agenda of 'keeping refugees out' has the potential to reach the limits of crimes against humanity. In parallel, the side effect of

10 UNHCR, 'Handbook on Procedures and Criteria for Determining Refugee Status under the 1951 Convention and the 1967 Protocol relating to the Status of Refugees' (HCR/IP/4/Eng/REV.1, 1992), para 28. 
the refugee crisis concept on shaping the societal view is also clarified. It is further concluded that considering the narrative developed to categorize and depict refugees as outsiders has been deliberately orchestrated with links to deliberate intentions of states to keep them out of their borders.

\section{Conceptualization of Refugee Crisis in the Modern World}

The fine line between immigration law and criminal law -on the national as well as international law level- are both stiff and lithe. For instance, because of the lithe nature of these two areas of law -crimmigration- has been developed as a term that encompasses the territory of crime and migration issues. Indeed, states are entitled to monitor movements of humans who come and go, in and out of their borders. It is understandable that issues linked with immigration are dealt with mechanisms of criminal law on the national law level worldwide. However, the problem begins with the attitude of states on a larger scale that policies are built upon keeping nearly all of the migrants out of the state's boundaries. In fact, these policies are also coupled with campaigns which are driven by 'anti-foreign' anxiety promoting an idea that refugees are illegal immigrants, breaching every possible right blessed by state's legal rules.

Beginning with the "anti-drug hysteria of the 1980s and 1990s, then the antiterrorism anxiety of the 2000s", we continue to backlash at refugees without knowing why we judge them and on what basis. ${ }^{11}$ We are not aware that refugees in most cases are fleeing from war torn lands or have been forced to leave due to some other reasons i.e., climate change. All of these produced/seemingly true reactions coming out of anti-drug hysteria/anti-terrorism anxiety and continuing misperception towards refugees continue their existence today due to racist and xenophobic provocations. Take for instance, regarding the stiff nature of immigration policies of states, the recent arising of the refugee crisis at the borders of Greece, which tell it all. What has happened at the front door of Greece, on no man's land, shows us that the concept of state sovereignty stands as a blockage against implementation of international legal obligations.

States continue to hide behind their cold-wired-built-up-walls and show no respect with their attitude of non-compliance to international legal regulations. Take for instance, the international community, in particular the European Union (EU) countries as being the most powerful political unit, which seems to lapse into silence by not taking any actions towards saving lives. The actions taken by the EU countries can be described as gathering large numbers of border guards to keep refugees out.

Looking at the current mass displacement and people who were kept waiting at the borders of Greece or have been tamped in overcrowded refugee camps such as Moria,

${ }_{11}$ César Cuauhtémoc García Hernández, 'Deconstructing Crimmigration' (2018) 52 University of California, Davis 197, 200. 
we now know better: states/the international community could have protected their well-beings if necessary/fundamental steps had been taken already.

By all means, guaranteed by the UDHR, every human being is born with alienable rights. In practice, even though inherent dignity of each and every individual is secured/locked by the Universal Declaration, some children are born into violence or they grow up by witnessing violence across the world. This also tells us that human beings are not born equal, even though beginning from the time of Magna Carta, it has been declared otherwise.

If the rights embedded in the Declaration are not to be taken literally, then they will be given limits. The governments will set the limits on one hand by promising to protect fundamental rights, on the other hand by taking away the very same rights due to some entitled rights of states, i.e. state security.

In an ideal world of human rights promising us an equal and dignified living, the affluence of refugees in large numbers would not be referred to links to crisis. In reality, we are not living in an ideal world. Yet given the empowering nature of HRL in particular in an unjust world to the victims, this Article looks at the conceptualization of crisis as a term with links to refugees, presented herein, through a human rights model of excellence as follows.

Movements of people from one state to another due to persecution -armed conflict or some other reasons pushing people to the shores of other countries- describes not the crisis attached to refugees, but the crisis that should be coupled with the concept of emergency response. Wording matters: bringing an explanation to issues in relation to mass movement of people through an emergency response approach in fact puts states and their leaders under the spotlight. Thus, we have to cross off the crisis wording to describe refugees' wants that need an immediate response. In this way we can remind states that they have shared responsibilities in dealing with the problems that individuals who are fleeing persecution face at their borders. Whereas placing the 'refugee' word before the crisis, signals the message that whatever refugees are facing happens because of their being at the center of a larger problem.

In the inspiration of Giorgio Agamben, a refugee person under the shadow of state sovereignty describes a " "sacred man" (homo sacer) within the state of exception who can be killed with impunity". ${ }^{12} \mathrm{He}$ is likely killed because he is seen as incompetent. He poses a danger to a working mechanism of the state. If he is not put aside for disposal then the state organism's powers to heal would be insufficient to overcome prospected disease spreading through/from this sacred man. Especially in the EU context, the crisis narrative is dictated as a result of the othering state of

12 Codrin Codrea, 'European Refugee Crisis: Legal Framework and European Political Effects' (2016) 2016 Rev Universul Juridic 72,73 . 
mind. With links to Brexit political scheme, skepticism produced against others is fed by anti-EU, right-wing extremism due to nationalist political movement. Others in this context are categorized as immigrants coming from different backgrounds: Muslim, Roma, Eastern-European, and African. For this reason, this Article's research objective carries an intent to uncover discriminative acts that refugees are put through. In that such research will help us to reveal the estimated numbers from the refugee status definition and eventually will detach them from the naming/ shaming language attached to the wording of crisis. By doing so it will allow us to critically discuss the question of why refugees are labeled as criminals -jeopardizing law and order of the society- even though they (refugees) are the ones who have been victimized as a result of state-operated offences against them in the first place. For instance, fluctuant hatred beginning from the year of 2015 has come to surface in the EU countries. In 2017, in Austria all elected political parties had predicated hatred for Muslim communities, which have turned into the political expression of closing borders by all means. In 2018, after Italy's elections, a coalition government ran a campaign that focused on the refugee crisis. In 2017, Marine Le Pen, urged nationalist parties to immobilize "invasion of immigrants in Europe."13

Refugee status and the othering state of mind towards them can be harmonically explained under the concept of victimhood. Indeed, there exists no generally excepted legal definition that describes the condition of being a victim. This might be due to the reason that victims "have something of the uncomfortable 'other' about them "'. ${ }^{14}$ Because of this otherness that is embedded in their experiences arising as a consequence of persecution, refugees are doubly victimized. In other words, othering mentality decorticates the human skin of refugees and helps/encourages states to treat them inhumanely. For instance, the Australian government has deliberately failed refugees by keeping them indefinitely in its offshore detention centers. The goal has been to prevent future refugees from even attempting to begin the journey of refuge.

This argument can be provoked by the supporters of state sovereignty rights, mentioned above. States are driven by the will of protecting their borders in their right. However, the meaning of state sovereignty should be interpreted elastically in light of the declared universal human rights. This approach appreciates the rights of refugees too. The presented idea herein represents the very basic human duty for one and another: we ought to help each other. As is created after the apartheid regime of South Africa in the 1970s, the Kew Gardens principles can guide us on how the chain of reaction against an atrocity that has not been caused by us should be. These principles constituting responsibility to help can be applied if "[T] here is a critical need; (2) the agent has proximity to the need; (3) the agent has the capability to assist;

\footnotetext{
13 Anna Carastathis and Myrto Tsilimpounidi, Reproducing Refugees Photographia of a Crisis (Rowman \&Littlefield International 2020), 5 .

14 Linda Asquith, Rebuilding Lives After Genocide Migration, Adaptation and Acculturation (Palgrave Macmillan 2019), 10.
} 
(4) the agent is likely the last resort from whom help can be expected ... (5) the action can be taken without disproportionate harm to the one providing assistance". ${ }^{15}$

In this regard, departing from the word - 'crisis'- and whether we should apply this description to define what refugees mean to us; this Article adds more to this discussion by stating that the description of crisis diminishes the human aspect of what refugees experience once they flee from their home lands. For instance, the following reasoning given in a sentence also bundles all of the negative opinions on refugees, making them others: "[w] hilst some will have actively fought to stay alive, others may have fled to safer areas, still surviving, but their actions may not be seen in the same light as those who resisted by fighting". ${ }^{16}$

Ripping off this 'shaming' terminology -that is indicated in the above-mentioned quoted sentence- when it comes to defining facts and status of refugees, this Article intends not to discuss how many refugees have fled from their homelands; instead, it presents what they endure.

Against this backdrop, the goal is to explain in what ways states' mistreatment against refugees extends to international crimes and whether this realization would influence the ICC to take action. This question is examined to understand whether such realization would trigger both origin and receiving states to recognize the human rights of their vulnerable groups at large and refugees in particular.

This Article interposes the rhetoric, which depicts refugees as 'escaping' individuals who in fact have ulterior motives of having better lives in some first-world country. If our goal is to settle a concrete, best served refugee status for people who flee from persecution, misconceptions do not help. Compassion towards refugees is important. Yet as is the case with the shaming language, portraying refugees as being in misery to make authorities pity them does not help to find more protective solutions either. At least, this is not in fact a 'humane' way of dealing with the problems that refugees face. Putting refugees on the frontlines with their faces covered up by dust and dirt in the hopes that this will affect and change policies and political approaches towards them will not get tangible results.

For this reason, the discussion set forth herein claims that emergency response should be developed to eliminate the violence that refugees have been enduring especially in most of the detention centers and refugee camps across the globe. This would assist us to embody refugee persons as human beings. The goal in this respect should not go into the direction of putting a spotlight on presumed and expected wretchedness of refugees, but to ask what the consequences of violence are.

\footnotetext{
15 David Hollenbach, 'Borders and Duties to the Displaced: Ethical Perspectives on the Refugee Protection System' (2016) 4 $\mathrm{J}$ on Migration \& Hum Sec 148,156.

16 Asquith (n 14) 11.
} 
There are many types of violence arising out of a variety of reasons including economic, political, gender, cultural and religious factors. Within the realm of IRL, violence indicates a different humanitarian crisis that needs an immediate response. Humanitarian crisis may refer to "any situations in which there is a widespread threat to life, physical safety, health, or basic subsistence that is beyond the coping capacity of individuals and the communities in which they reside". ${ }^{17}$ In this regard, human beings are forced to move for many reasons/push factors including

- environmental disasters such as hurricanes, tsunamis, earthquakes, drought;

- serious diseases, in other words epidemics and pandemics;

- human-made events, e.g., any form of violence such as armed conflict, political oppression, societal torture and furthermore starvation, and famine.

Departing from this ongoing analysis, it is set to identify the movement of persons and states' abusive policies with links to crimes against humanity of the Rome Statute -with the aim of characterizing the violence conceptualized by this Article-, further.

\section{Mass Movement of Humans Facing the Threat of Crimes Against Humanity}

This part brings together ICL and IRL to examine the following question: What are the major modern world incidences in which refugees are mistreated, shot to death, ignored or not even welcomed to cross other states' borders that can be detected as crimes against humanity, e.g., torture or persecution?

It should be noted that the discussion of this part does not seek ways of ranking two branches of international law, namely ICL and IRL. Rather it develops its main argument based on the intersection that lies at the corner of these two different (and connected) fields.

Movement of human beings creating a nexus/interaction between ICL and IRL can be exemplified in the following sentences. For instance, the chain of acts constituting ethnic cleansing can be classified as deportation and forcible transfer. In comparison to the crime of genocide, ethnic cleansing differs by the very existence of intent. However, the purposeful action to create fear - such as bombing, destroying property, etc. - and uncertainty extending to the threshold of societal torture would also cause the targeted population to flee. Take for instance, the cases of child soldiers. These children who are forced to kill and commit atrocities may seek ways of fleeing to find a refuge in other countries. A further example can be provided in regard to incidences

Susan F Martin, 'New Models of International Agreement for Refugee Protection' (2016) 4 J on Migration \& Hum Sec 60, 60. 
of genocide and its aftermath. Looking through the pages of human history and the creation process of international refugee law regiment, genocide survivors sought ways of settlement abroad after Hitler's genocide, for instance.

This research acknowledges that -as is explained in the previous part- there are a variety of reasons why people are forced to migrate. In one aspect, people might flee because of the atrocities (falling under the international crimes category) that have happened in their homelands. This is where ICL and IRL meets with respect to forced migration. This Article on the other hand looks at the other side of the coin: the incidences in which people escape from persecution due to race, religion, environmental disasters, armed conflict, international crimes and so on and so forth, and are victimized further due to receiving the states' atrocious conducts.

As of January 2020, there were 146 parties to the 1951 Refugee Convention, and 147 to the 1967 Protocol, yet still refugee protection poses as a problem to this day across the world. As is exemplified in the following part, there are many cases that show state brutality against refugees that can be examined with links to crimes against humanity. This is for the examination of this Article in which ICL and IRL also intersect. Further, the research conducted herein claims that such overlap between these two disciplines is triggered by the refugee crisis discourse too.

\section{A. Setting of the Scene: How Refugees are Treated by States.}

This part is articulated to reverberate major significant incidences of refugees across the world and in particular some wealthier countries. The reason for directing the attention of readers to these selected countries can be prescribed in two respects: First, wealthier countries as can be categorized as 'industrialized and developed states' that seem to promote and protect the human rights of people. Yet incidences tell another story with the same sword. Second, their well-developed-individualoriented way of living attracts many people from all around the world. We presume that for some people who are born into violence, these lands resemble a dream come true to start a new life. That is why 'they' travel 'that far' to seek asylum, rather than staying and fighting or taking sanctuary in a neighboring country. In consideration of this perspective, the following paragraphs demonstrate a set of scenes depicting how refugees are treated in the camps or at the borders of some wealthier states, for instance. This analysis thus shows that in light of Susan Sonntag's standpoint, it disaffirms the idea that human suffering happens in the more distant and exotic places within the context of "colonial reflex". ${ }^{18}$ Additional examples are further set forth in some other developing countries' refugee camps hosting large numbers of individuals. This Article provokes the idea that global powers treat refugees poorly

Susan Sontag, Regarding the Pain of Others (Picador 2004), ff 61-64. 
because these states -by creating an unwelcoming aura- in fact aim to shut their doors/ borders to fleeing individuals. The other less wealthy or developing countries with large refugee camps or overpopulated refugee communities are falling short in some respects due to having limited resources to begin with. However, the latter countries mostly respond more generously than the others throughout the crisis timeline. For instance, Rohingya refugees have been living in Bangladesh's refugee camp named Cox's Bazar district/Kutupalong Refugee Camp. Bangladesh resembles a promising way of protecting refugees, in contrary to what refugees endure in Libyan refugee camps: torture and rape have been reported in Libya's refugee camps by the Women's Refugee Commission, for instance. Under the shadow of the Libyan civil war, the ICC Prosecutor Fatou Bensouda's Office "has facilitated progress in a number of investigations and prosecutions relating to crimes against migrants in Libya $"{ }^{19} \mathrm{EU}$ Member States in cooperation with Libyan authorities aim to stop departures of refugees. Recently a group of lawyers have gone a step further asking the ICC to investigate the EU as well by holding it responsible for crimes against humanity as a result of thousands of deaths that happened in the Mediterranean.

The Trump administration in the USA made an effort of separating asylum-seeking families by drifting parents and children apart during the process at the border. Parents got prosecuted, children were placed into federal custody and parents were further detained for immigration proceedings. ${ }^{20}$ The same administration recently 'designed' a program (which was subsequently blocked by a appeals court) called Remain in Mexico (MPP) to force about 60,000 asylum seekers to wait in Mexico while their requests are heard. For example, a Brazilian mother with two children has been staying in Ciudad Juárez for three months, across the border from El Paso, Texas. She has been waiting for the moment to come when she and her children would present themselves at the border, as is required for those seeking asylum. They have been "sleeping on the floor with the children in a hall". ${ }^{21}$ It means that any delay can cause serious results considering her children have critical health conditions. Yet due to the spread of Covid-19, she was informed that MPP hearings have been suspended for some time. The policy of the USA represents the same mentality of the refugee crisis response embodied after 2015 by the EU states. In the same vein 'The Jungle' camp in the French city of Calais represented the same mindset of abandonment of 'others/outsiders'. Hundreds of unaccompanied children have been living in Al-Hol

19 UN News, "Violence, Atrocities And Impunity’ Reign Throughout Libya, ICC Prosecutor Tells UN Security Council' (6 November 2019) < https://news.un.org/en/story/2019/11/1050771> Date of access 9 June 2020. Further see International Criminal Court, 'Situation in Libya ICC-01/11'<https://www.icc-cpi.int/libya > Date of access 9 June 2020.

20 Aaron Korthuis, 'Detention and Deterrence: Insights from the Early Years of Immigration Detention at the Border' (2019) 129 Yale LJ F 238, 240.

21 Jasmine Aguilera, 'Many Asylum Seekers in Mexico Can’t Get U.S. Court Hearings Until 2021 A Coronavirus Outbreak Could 'Devastate' Them' (Time, 14 May 2020) < https://time.com/5830807/asylum-seekers-coronavirus-mpp/?utm source=newsletter\&utm_medium $=$ email\&utm_campaign=the-brief\&utm_content $=20200518 \&$ xid $=$ newsletter-brief $>$ Date of access 18 May 2020. 
camp in northeast Syria. This camp is overwhelmed with mainly women and children who fled the last battlefields of the Islamic State of Iraq and the Levant (ISIL or ISIS).

Stories of refugees who physically wanted to harm themselves in detention centers of Australia have been issued by mass media. It has been detected in the offshore detention centers of Australia, mainly Nauru, Manus Island (recently closed) and Papua New Guinea, where mistreatments extended to the crimes against humanity of torture. Examples can be given as overcrowded and unsanitary detention centers, sexual and physical abuse, minimum access to food and so forth. A communication in the purpose of "calling upon the ... OTP ... to launch an investigation regarding crimes against humanity which may have been committed against asylum seekers and refugees" in these three places was submitted subsequently. ${ }^{22}$ Further in a letter written by the independent MP for Clark, Andrew Wilkie, the Office answered the concerns over whether such treatments of Australian policy makers towards refugees and asylum seekers in detention centers amount to crimes against humanity. The OTP in its response confirmed that Australia's policy in its offshore detention centers constitutes "cruel, inhuman, or degrading treatment" and the treatments that 'detainees' are subjected to are unlawful under international law. ${ }^{23}$

In consideration of this designation by the OTP, it is required to identify the severity of the treatments that detainees/refugees have endured in not only detention centers -controlled in place by Australia- but also in the other wealthier countries. With respect to the provided examples so far, we can conclude that these treatments also form psychological torture aiming to inflict pain. Ongoing discussion is explained and expanded further in consideration of the gravity requirement of crimes against humanity under the Rome Statute.

\section{B. How Refugees Are Othered.}

What it takes to consider that a crime is grave enough - considering the concept of gravity - has been used to describe evilness of international crimes. For example, the Rome Statute of ICC repeatedly refers to the grave nature of international crimes in its text. In the previous part's analysis, considering some leading states' abusive attitude/policies against refugees, what would it take then for the ICC to consider these acts as amounting to crimes against humanity for instance? In other words, what is it that is embedded in the abusive acts against refugees that would make the OTP to take them into consideration? This is discussed in this part.

\footnotetext{
Communiqué to the Office of the Prosecutor of the International Criminal Court Under Article 15 of the Rome Statute, 'The Situation in Nauru and Manus Island: Liability for Crimes Against Humanity in the Detention of Refugees and Asylum Seekers' $<$ https://c5e65ece-003b-4d73-aa76-854664da4e33.filesusr.com/ugd/b743d9_e4413cb72e1646d8bd3e8a8c9a466950. pdf > Date of Access 20 June 2020 [hereinafter ICC Australia Communication].

23 International Criminal Court The Office of the Prosecutor, (Ref. OTP-CR-322/14/001, 12 February 2020) <https://uploads. guim.co.uk/2020/02/14/200213-Andrew-Wilkie-Response-from-International-Criminal-Court-Australian-Governmenttreatment-of-asylum-seekers_(1).pdf> Date of access 21 May 2020.
} 
Moral, political, and legal philosophers including Immanuel Kant and Hannah Arendt have developed certain types of responses to various atrocities and horrors, including genocides, terrorist attacks, mass murders, and tortures. In order to describe malicious acts of horrifying individuals these philosophers conclude that we need a simple yet strong word. It seems that we cannot capture the moral significance of the very acts of these perpetrators as them being 'wrong' or 'bad'. We have an urgent need to other them as evils. When we encounter that wrong or bad act, very, as an adjective falls short. "Only 'evil', it seems, will do". ${ }^{4}$

Hannah Arendt, in pursuance of this need, after World War II defined radical evil "as evil that makes human beings superfluous, reducing them to 'bare life', or life not worth living". ${ }^{25}$ Considering the previous part's incidences describing abusive treatments conducted by states against refugees, the question becomes whether we refer to these kind of treatments as evil acts forming one of the international crimes or these acts in fact appear as lesser evil that, e.g., they do not have the effect of shocking the conscience of human kind as much as crimes against humanity do?

In most cases, as is exemplified in the previous part of this Article, we encounter an ideal victim (refugee) who would fit in the dynamics of an international jurisprudence: She/he is weak, vulnerable and dependent. On the other hand, we are pushed to look at the other side of the coin, which in fact is an illusion. Conservative rhetoric by creating a shaming and naming language in relation to narratives of movements of humans, leads us to a place where we find ourselves believing in a composed idea that they are not in that bad a situation. For this reason, through the reflection of the othering mind state, each refugee by not meeting the requirements of an idolized refugee persona is seen as a burden that needs to be shaken off the shoulders of individuals forming the asylum state's society. The question is even though as is stated in its letter, the OTP delineated treatment against asylum seekers and refugees in Australian offshore detention centers as inhuman and degrading, what is the breaking point then that such treatments cannot be elevated to the level of international crimes; i.e., crimes against humanity of torture?

In search for the ideal victim among refugees, are we not considering states as their ideal offenders, which would also undo their victimization?

Hiding behind the curtains of their sovereignty rights, are we not considering states ugly enough in their dealings with refugees then? If we desperately need an ideal victim as a refugee person in the absence of an ideal perpetrator, how does the ICL respond to the search for an ideal victim status?

\footnotetext{
24 David Sussman, 'Review of Kant's Theory of Evil: An Essay on the Dangers of Self-love and the Aprioricity of History by Pablo Muchnik' (Notre Dame Philopsohical Reviews An Electronic Journal, 19 July 2010) <https://ndpr.nd.edu/news/ kant-s-theory-of-evil-an-essay-on-the-dangers-of-self-love-and-the-aprioricity-of-history/> Date of access 22 May 2020.

25 Ioannis Kalpouzos and Itamar Mann, 'Banal Crimes against Humanity: The Case of Asylum Seekers in Greece' (2015) 16 Melb J Int'l L 1, 2.
} 
The ICC's Rules of Procedure and Evidence Rule 85 defines victim as follows: "Victim means natural persons who have suffered harm as a result of the commission of any crime within the jurisdiction of the Court... ". ${ }^{26}$

This definition is too broad. However, gravity of mistreatment against refugees can be weighed by considering certain aspects. For instance, refugees by taking risky journeys are faced with death. Recent incidents have shown that the Greek Government has expelled refugees crossing the Aegean Sea from the Europe's borders. Refugees were sailed to the edge of Greek territorial water. Mainly women and children embarking a journey on an unsecure rubber dinghy were abandoned on the high sea. ${ }^{27}$ While Greek officials were systematically pushing back refugees, "Frontex has denied knowledge of, or involvement in, pushbacks". ${ }^{28}$ Refugees are kept out of the destination state's borders day and night in cold and rainy days. In refugee camps they are treated as if they are disposable. They are left aside and othered. In detention centers and camps, refugees experience deprivation of liberty for an indefinite amount of time. Uncertainty is brutal at any time, and even more brutal if it is experienced under prison-like conditions. Moreover, at perilous times such as from the beginning of the spread of COVID-19 worldwide, this pandemic also has been threatening refugees who have been living in over-crowded-unsanitary camps. This also can be seen as a response facilitated and fed systematically against refugees. Yet still debated aspects of what has been done to refugees do not provide us an undisputed list of qualifications to reach a conclusion whether crimes against humanity have been committed. It means that even though inhuman and degrading can be put as labels on states' policies against refugees, still these kinds of treatments are not found spectacular enough to be put under the international crimes category in the eyes of the OTP, e.g., with links to the Australian policy: 'whatever' refugees are going through throughout their journeys are not seen as shocking enough to the world.

States' border regimes -coupled with racist, anti-foreign hysteria- create an understanding that refugees unlawfully set foot on foreign soil and it is absolutely fine to mistreat them in reference to the following justifications: they talk a different language, come from a different background, were born in a different country - they are not locals. This attitude, in the simplest way possible, is called racism. In a racist view, all of these features make migrants at large and refugees in particular not capable of blending in a new society.

\footnotetext{
26 Rules of Procedure and Evidence of the International Criminal Court 2002, UN Doc. PCNICC/2000/1/ Add.1, Rule 85.

27 Patrick Kingsley and Karam Shoumali, 'Greece turning back migrants by abandoning them at sea' (The New York Times, 25 August 2020) <https:/www.nytimes.com/2020/08/14/world/europe/greece-migrants-abandoning-sea.html> Date of access 19 January 2020.

28 Katy Fallon, 'EU border force 'complicit' in illegal campaign to stop refugees landing' (The Guardian, 24 October 2020) $<$ https://www.theguardian.com/global-development/2020/oct/24/eu-border-force-complicit-in-campaign-to-stop-refugeeslanding $>$ Date of access 19 January 2020.
} 
What should the solution to protect refugees be then amidst the racist mentality embedded in most societies across the world especially considering that international crimes have such a high threshold to be achieved? The components of this question can be divided into the following empirical questions:

- Whether the deterrence of the ICL is limited for occurrences that harbor certain requirements to be considered as one of the international crimes; if yes then

- When it comes to the goal of diminishing abusive state agents' acts fed by abusive state policies developed against refugees, what kind of recipe would be practical to protect refugees in the first place?

This is answered in the concluding remarks of this Article, in the following paragraphs.

\section{Conclusion}

In this time and age, it is painfully evident that human beings are forced to move due to a number of reasons such as race, political and gender identity, civil war, armed conflict, climate change, and honor killings. Some of these reasons have led to mass movements of human beings, whereas some other reasons can make a particular individual to flee. The most striking part of the entire journey of refugees reveals itself through the inattentive and abusive characterization of most of the liberal democratic states' refugee policies in the modern world. Calais jungle in France (closed in 2016), offshore detention centers of Australia, Greek refugee camps, overwhelming death tolls in the Mediterranean sea due to the desperate attempts of refugees to reach the EU countries, the Trump administration's policy to keep refugees out have forced human rights defenders and scholars to question the international community's moral understanding at large: Do we still yearn for the thinking and doing of categorization of some of the people or communities to turn them into others? It is in fact inevitably present in front us -if we force ourselves to look through the pages of human historythat many historical and modern conflicts have been shaped by orchestrated violence against certain groups of (ethnic, racial or religious) people. This mindset of making some people scapegoats of some ulterior motives fed by a dominant conservative political ideology has deterritorialized people en masse to this day. When it comes to the protection of these people who have been already victimized in their homelands, they continue to suffer in the countries of asylum due to inhuman treatments conducted as a result of ongoing refugee policy of the hosting states.

In short, we keep failing refugees. It is clear from modern world incidences that we -as a humanity connected one to another in a harmonized way also due to globalization and rising trends growing out of online communication platforms- have not satisfied 
the foundations of humanitarianism and the following reaction that is expected to come: emergency response to protect fellow human beings who have escaped from violence or persecution. Overwhelming evidence of brutality against refugees ranging from sexual abuse to trafficking of human beings has come to surface. Yet beginning with the EU countries, the others including transit and host states have remained silent in the face it. Individuals as being part of diverse societies across the world mostly have a negative image about refugees in their minds that is shaped by refugee crisis rhetoric. Refugees have been looking for a safe place for residence and it has been deliberately held back from them due to the otherness mentality that has fed us into thinking that before their arrival we had been doing good.

Most states are participating as a driving force of this violence, by unwelcoming policies directed against these particular ethnic, racial or religious groups who happen to be refugees. Adding to the discussions on elevating the violence of states in this respect to the level of crimes against humanity, this research contributes to the following.

In the context of crimes against humanity, humanity refers to both humankind and the spirit of human nature. Bassiouni considers crimes against humanity as grievous enough to 'shock the conscience of mankind'. ${ }^{29}$ These crimes shock humankind's conscience, even though specific instances of such actions may not threaten peace and security. ${ }^{30}$ Viewed along these lines, 'crimes against humanity' as a term "signifies that all humanity is the interested party and that humanity's interest may differ from the interests of the victims". ${ }^{11}$ The question becomes then whether such a deep understanding can be established and implemented for abusive treatments against refugees. In that "violating humanness and offending against humankind are not equivalent"- sadistic rape or murder degrades humanity of its victim without impacting the interests of the entire human race. ${ }^{32}$

The Rome Statute's article 7(1)(a)-(k) establishes the perpetration of the acts enumerated in the context of crime against humanity, and reads as follows:

"The acts must constitute an attack directed against any civilian population; the acts must be widespread or systematic in nature; the attack must be pursuant to, or in furtherance of, a State or organisational policy to commit such attacks; the acts must be committed as part of the attack; the perpetrator(s) must have known that the conduct was part of or intended the conduct to be a part of such an attack."

\footnotetext{
M Cherif Bassiouni, 'International Crimes: Jus Cogens and Obligatio Erga Omnes' (1996) 59(4) Law and Contemporary Problems 63, 69.

30 David Luban, 'A Theory of Crimes Against Humanity' (2004) 29 Yale Journal International Law 85, 88.

31 ibid 88.

32 ibid 90.
} 
This regulation can be completed on the point of:

"Crimes against humanity are typically committed against fellow nationals as well as foreigners; [c]rimes against humanity are international crimes; [c]rimes against humanity are committed by politically organized groups acting under color of policy; [c]rimes against humanity consist of the most severe and abominable acts of violence and persecution; [c]rimes against humanity are inflicted on victims based on their membership in a population rather than their individual characteristics." ${ }^{33}$

After all of these analyses, it can be concluded that systematic and widespread mistreatment against refugees has the equilibrium of shocking the conscience of mankind. For example, considering major recent incidences that were presented in Part III of this Article, the ongoing struggle of refugees has been seen and felt across the world. Many states' policies of refugee related regulations are performed by their agents as part of a systematic attack oriented towards civilians who are identified as refugees, with the knowledge of the attack. However, e.g., the conditions of attack and persecution have not been interpreted narrowly enough to make these terms clear, which leaves an open door, e.g., to the OTP to decide whether to take a step forward for investigation.

Indeed, the 1951 Refugee Convention does not provide a definition on persecution. Even though people are promised to be protected on the face of it, there exists no international regulation that defines the phenomenon of persecution. This can be due to the reason that "[i]t is possible that all forms of persecution have not yet been identified or codified in international human rights law"34. Since persecution is not identified, states' persecution against refugees is not considered intense enough to be aggravated to the international crimes category. The only evidence that we have regarding the definition of persecution is prescribed by related conventions. For example, the definition that is adopted by the African Union as a regional convention and in a similar fashion, the Cartagena Declaration has been adopted by Latin American Countries. In 1984, the Latin American countries adopted a similar definition in the Cartagena Declaration.

It can be concluded that if the requirements are indeed met to accept that a crime against humanity is at stake then states will readily treat refugees more humanely. For instance, in 'Banal Crimes Against Humanity: The Case of Asylum Seekers in Greece', Ioannis Kapouzos and Itamar Mann suggest that in order to hold individual agents of the government criminally responsible, it is crucial to get the ICC involved to protect refugees from any form of abuse. In this direction, these authors conclude

\footnotetext{
ibid $93 \mathrm{ff}$.

34 Alice Edwards, 'Age and Gender Dimensions in International Refugee Law', in E Feller, V Türk and E Nicholson (eds), Refugee Protection in International Law: UNHCR's Global Consultations on International Protection (Cambridge University Press 2003), 50.
} 
that involvement of the ICC's direct attention will protect vulnerable populations who have become voiceless under the shadow of powerful states. That is a fair determination as the ICC has an important role over prevention of international crimes. Kapouzos and Mann suggest that banal crimes constituting violence directed against refugees by state officials should be taken into consideration by the ICC too. As was exemplified above, the OTP has been investigating Libyan authorities' mistreatment of refugees in refugee camps. Yet the Prosecutor has not given the same consideration to, e.g., Greek or Australian States' misdemeanors.

The UNHCR has published its latest annual report. It is stated in this report that at the end of 2019 as a result of various human rights violations and violence at large, 79.5 million people were forcibly displaced worldwide. ${ }^{35}$ However, as the threshold for reaching the limits of international crimes is set high, it is obviously questionable if IRL has satisfying tools to force states to comply with the standards that refugee protection requirements seek for. In fact, many more solutions can be provided such as voluntary repatriation, resettlement and integration when it comes to refugee protection. On the other hand, what is left for refugees who are kept out of states' borders or either in camps or elsewhere and who wait for their asylum applications' outcome suffer from doubled victimization due to uncertainty that they are doomed. Thus, if we want to respond to the question of whether ICL can resolve the refugee crisis quagmire; the answer is both yes and no in confirmation with the recent researches. Yes, as long as influential institutions such as the ICC adamantly seek ways to backlash states' arbitrary refugee policies. No, as long as influential institutions such as the ICC pick and select incidences for their further examinations.

\footnotetext{
Peer-review: Externally peer-reviewed.

Conflict of Interest: The author has no conflict of interest to declare.

Grant Support: The author declared that this study has received no financial support. 


\section{Bibliography}

Aaron Korthuis, 'Detention and Deterrence: Insights from the Early Years of Immigration Detention at the Border' (2019) 129 Yale LJ F 238.

Aguilera J, 'Many Asylum Seekers in Mexico Can't Get U.S. Court Hearings Until2021 ACoronavirus Outbreak Could 'Devastate' Them' (Time, 14 May 2020) <https://time.com/5830807/asylumseekers-coronavirus-mpp/?utm source $=$ newsletter\&utm medium $=$ email\&utm campaign=thebrief\&utm_content $=20200518 \&$ xid=newsletter-brief $>$ Date of access 18 May 2020.

Asquith L, Rebuilding Lives After Genocide Migration, Adaptation and Acculturation (Palgrave Macmillan 2019), 10.

Bassiouni M C, 'Universal Jurisdiction for International Crimes: Historical Perspectives and Contemporary Practice' (2001-2002) 42(1) Virginia Journal of International Law 81.

Bassiouni M C, ‘International Crimes: Jus Cogens and Obligatio Erga Omnes’ (1996) 59(4) Law and Contemporary Problems 63.

BBC News, 'Syria civil war: Germany holds unprecedented state torture trial' (BBC, 23 April 2020) $<$ https://www.bbc.com/news/world-europe-52393402> Date of access 23 April 2020.

Convention Relating to the Status of Refugees (adopted 28 July 1951, entered into force 22 April 1954) 189 UNTS 137 (1951 Refugee Convention).

Communique to the Office of the Prosecutor of the International Criminal Court Under Article 15 of the Rome Statute, 'The Situation in Nauru and Manus Island: Liability for Crimes Against Humanity in the Detention of Refugees and Asylum Seekers' <https://c5e65ece-003b-4d73aa76-854664da4e33.filesusr.com/ugd/b743d9_e4413cb72e1646d8bd3e8a8c9a466950. pdf $>$ Date of Access 20 June 2020 [hereinafter ICC Australia Communication].

Codrea C, 'European Refugee Crisis: Legal Framework and European Political Effects' (2016) 2016 Rev Universul Juridic 72.

Durieux J F, 'The Duty to Rescue Refugees' (2016) 28 Int'l J Refugee L 637.

Edwards A, 'Age and Gender Dimensions in International Refugee Law', in E Feller, V Türk and E Nicholson (eds), Refugee Protection in International Law: UNHCR's Global Consultations on International Protection (Cambridge University Press 2003).

Fallon K, 'EU border force 'complicit' in illegal campaign to stop refugees landing' (The Guardian, 24 October 2020) <https:/www.theguardian.com/global-development/2020/oct/24/eu-borderforce-complicit-in-campaign-to-stop-refugees-landing > Date of access 19 January 2020.

Goodwin-Gill G, The Refugee in International Law ( $2^{\text {nd }}$ ed, Oxford: Clarendon Press 1996), 2.

Hernández C, 'Deconstructing Crimmigration' (2018) 52 University of California, Davis 197, 200.

Hollenbach D, 'Borders and Duties to the Displaced: Ethical Perspectives on the Refugee Protection System' (2016) 4 J on Migration \& Hum Sec 148.

International Criminal Court The Office of the Prosecutor, (Ref. OTP-CR-322/14/001, 12 February 2020) <https://uploads.guim.co.uk/2020/02/14/200213-Andrew-Wilkie-Response-fromInternational-Criminal-Court-Australian-Government-treatment-of-asylum-seekers_(1).pdf $>$ Date of access 21 May 2020.

Kalpouzos I, 'International Criminal Law and the Violence against Migrants' (2020) 21 German Law Journal 571.

Kalpouzos I and Mann I, 'Banal Crimes Against Humanity: The Case of Asylum Seekers in Greece', (2015) 16 Melbourne J. Int'l L 1.

Kingsley P and Shoumali K, 'Greece turning back migrants by abandoning them at sea' (The New 
York Times, 25 August 2020) <https://www.nytimes.com/2020/08/14/world/europe/greecemigrants-abandoning-sea.html $>$ Date of access 19 January 2020.

Luban D, 'A Theory of Crimes Against Humanity' (2004) 29 Yale Journal International Law 85.

Martin S F, 'New Models of International Agreement for Refugee Protection' (2016) $4 \mathrm{~J}$ on Migration \& Hum Sec 60.

Protocol relating to the Status of Refugees (adopted 31 January 1967, entered into force 4 October 1967) 606 UNTS 267 (1967 Protocol).

Rome Statute of the International Criminal Court, July 17, 1998, 2187 U.N.T.S. 90 [hereinafter ICC Statute].

Rules of Procedure and Evidence of the International Criminal Court 2002, UN Doc. PCNICC/2000/1/ Add.1, Rule 85.

Sontag S, Regarding the Pain of Others (Picador 2004), 61-64.

Sussman D, 'Review of Kant's Theory of Evil: An Essay on the Dangers of Self-love and the Aprioricity of History by Pablo Muchnik' (Notre Dame Philopsohical Reviews An Electronic Journal, 19 July 2010) <https://ndpr.nd.edu/news/kant-s-theory-of-evil-an-essay-on-thedangers-of-self-love-and-the-aprioricity-of-history/> Date of access 22 May 2020.

UN News, "Violence, Atrocities And Impunity' Reign Throughout Libya, ICC Prosecutor Tells UN Security Council' (6 November 2019) < https://news.un.org/en/story/2019/11/1050771> Date of access 9 June 2020. Further see International Criminal Court, 'Situation in Libya ICC-01/11' $<$ https://www.icc-cpi.int/libya $>$ Date of access 9 June 2020.

UNHCR, 'Glossory'<https://www.unhcr.org/449267670.pdf441> Date of Access 24 June 2020.

UNHCR, 'Solutions'<https://www.unhcr.org/solutions.html> Date of access 25 June 2020.

UNHCR, 'Handbook on Procedures and Criteria for Determining Refugee Status under the 1951 Convention and the 1967 Protocol relating to the Status of Refugees' (HCR/IP/4/Eng/REV.1, 1992).

Universal Declaration of Human Rights (adopted 10 December 1948 UNGA Res 217 A(III) (UDHR). 